\title{
A Performance Measurement System for the R\&D Activities in The Software Sector
}

\author{
Edibe Beste Ersoyak ${ }^{2}$, Sercan Ozcan ${ }^{1,2}$ \\ ${ }^{1}$ Portsmouth Business School, University of Portsmouth, Portsmouth, UK \\ ${ }^{2}$ Department of Engineering Management, Bahcesehir University, Istanbul, Turkey \\ E-mail: beste.ersoyak@ekol.com, sercan.ozcan@port.ac.uk
}

\begin{abstract}
R\&D activities in the software sector have a key role as they lead to sustainability of the sector and rapid development activities with shorter cycles. The importance of R\&D activities in this sector requires an effective performance measurement system for the companies to evaluate the performance of $R \& D$ activities. Hence, this study aims to establish a performance measurement system that is applicable to the software industry. The study consists of a sequential mixed method where first key performance indicators, drawn from preliminary interviews and then the data from 2012 to 2016 are collected and analyzed. The results are interpreted by conducting in-depth interviews with the performance management department. This study uses various performance indicators for the R\&D oriented sectors combining them with the new KPIs that are specific to the software sector. The implemented method is used to rank the performance of a software company effectively. The study offers many performanceoriented interrelationships between financial, innovation, education, customer-oriented and organizational factors. The study also offers interesting findings, related to the quality versus quantity measures indicating highly qualified employees leading to a higher quality levels in research and patent applications rather than higher number of outputs.
\end{abstract}

Keywords: R\&D Management, Performance Management, Software Sector, Performance Measurement 


\section{1) INTRODUCTION}

Organizations have to focus on R\&D activities and try to solve their problems in response to the changing customer needs, the increase of the market competition, resource scarcity and economic restrictions (Kulatunga U. et al, 2006). R\&D activities have shown a significant change throughout the history. While, earlier, companies have used push concept with the assumption of "more R\&D" leads to "better new products, then this overview changed to "market-pull" strategy which concentrates on analyzing customer and market requirements. Starting from the 1990s, R\&D gained the aspects of being time-based; heavily focusing on quality, customer satisfaction, being flexible and building strategic collaborations (Rothwell 1994 ). In addition to these features, today's R\&D gives a significant importance to the open innovation related R\&D (Chesbrough 2003). Today, companies have been challenged to develop the effectiveness and efficiency of their R\&D activities with the changing business environments (Kerssens-van Drongelen and Bilderbeek, 1999). However, R\&D performance measurement might become a hard issue due to its inherent ambiguity (Bremser and Barsky, 2004). Therefore, throughout the literature, many studies have been conducted to measure R\&D performance in the most effective way.

In today's world, R\&D activities constitute a significant part of many sectors. Software sector (SWS) is one of the sectors that R\&D activities play a huge role for its improvement and the importance of this sector shows a significant increase in recent years. SWS is crucial because of two main reasons. Firstly, all technological devices consist of either high or low level of software that includes millions of lines of code and those Softwares are integrated into almost all sorts of products (Daly,2013). SWS can be considered in the edge of being a generalpurpose technology due to its high diffusion rate and availability of smart objects in our daily life. The second ground is that SWS has a very short innovation cycle (Goldman,2012). In fact, this sector has been seen unpatentable until the years of the 1980s due to its short innovation cycle and high intangibility(Mossoff,2014).

While working on R\&D activities in the software sector, firstly the current situation is evaluated in the research part of R\&D. Afterwards, software R\&D activities are carried out according to the necessities that might occur in the future. In the evaluation process software related problems in the previous software are identified based on determining customers' problems. In the research process, companies define future requirements to develop the current software or create totally a new software. On the other hand, in the development process of 
$\mathrm{R} \& \mathrm{D}$, a new software or the current updated software with fixes for identified problems is tested. Additionally, the general purpose which is increasing quality and reducing cost is tried to be achieved by the software companies throughout the entire R\&D processes (PWC,2016). As a result of the high importance of R\&D activities in the SWS, there is a clear need for measuring how well an software company runs its R\&D activities. Here, performance measurement plays an important role in the improvement of R\&D activities in the SWS as in the other sectors. That is because if we do not control the things which are really important for the company, we cannot know whether there is an improvement or something needed to be developed and thus further decisions can be suboptimal (Tregear,2014). Unfortunately, the number of studies focusing on meeting this clear need is not satisfying enough. Therefore, this study has chosen the aim of adapting an effective performance measurement system (PMS) into the R\&D of SWS since the importance of R\&D in the SWS is so high. The study attempts to find the most suitable performance measurement approach and the KPIs to create an effective PMS for the software R\&D activities. Further, the paper will focus on correlations for various combinations of KPIs to see the relations between them. Lastly, the newly created PMS and results will be evaluated under the light of secondary in-depth interviews conducted with the managers of the sample company.

\section{2) LITERATURE REVIEW IN R\&D PERFORMANCE MEASUREMENT}

There are different kinds of multi-dimensional PMSs designed by different scholars. The most used PMSs are the Balanced Scorecard (BSC) (Kaplan and Norton,1996), EFQM Business Excellence Model(EFQM,2013), Performance Pyramid (Lynch and Cross, 1991), Performance Prism (Neely and Adams, 2000) and Benchmarking.

Performance pyramid shows a hierarchical view of an organizational performance measurement (Somayajulu, 2014). Performance pyramid mainly aims linking strategy of the organization with its operations by interpreting objectives based on the top down and measures based on the bottom-up approach (Striteska and Spickova,2012). On the other hand, Balanced Scorecard attempts to provide managers a comprehensive view of the business and help them to concentrate on the critical areas that drive the organizational strategy ahead (Wongrassamee et al., 2003). As for benchmarking model, it is comparison and measurement of an organization against the toughest competitors or industry leaders (Camp, 1989). 
These above mentioned performance measurement related models are applied in R\&D field in different ways. Scholars have focused on various features of performance in R\&D and they developed different PMSs to evaluate the performance of R\&D activities. Some scholars separated various type of metrics used in R\&D into three different categories as quantitative objective, quantitative subjective and qualitative subjective metrics (Chiesa et al., 2009). Further, some others suggested a PMS by separating R\&D performance measurement metrics into a group of four.

- Input: It is the quantity and quality used into operations which shape the performance.

- $\quad$ Process: This indicates analyzing the activities related to R\&D function such as project selection, product development, etc.

- Output: This describes monitoring R\&D regarding outputs such as patents, publications, etc.

- Outcomes: This means the achievements of R\&D that add value to the organization. Examples of this group are a reduction of cost, sales from the new products, etc. (Chiesa et al., 2009)

Bremser and Barsky (2004) and Lazzarotti et al., (2011) have taken BSC as the basis for the measurement of the $R \& D$ activities and approached to the $R \& D$ performance measurement similarly. Bremser and Barsky (2004) integrated stage-gate approach with the balanced scorecard method and proposed several KPIs for the R\&D activities' performance evaluation. These KPIs are shown in Table 1.

Table 1: Most frequently used R\&D metrics (Bremser and Barsky,2004)

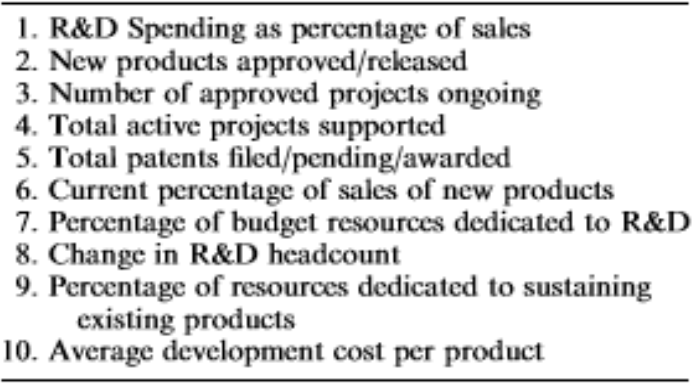

Lazzarotti et al.(2011) evaluated R\&D performance in three phases. The first phase is the evaluation of a company's performance by comparing it $\Delta t$ time before. The second is the analysis of the targeted 
performance. The last phase focuses on the benchmarking side that implies the comparison of the company with its competitors. The measurement system is based on BSC and it consists of five different perspectives that have different indicators. These perspectives are (1) financial side, (2) customer side, (3) internal and business perspective, (4) innovation and learning and lastly (5) alliances and network perspective. Lazzarotti et al.(2011) 's performance measurement system is shown in the Figure 1.

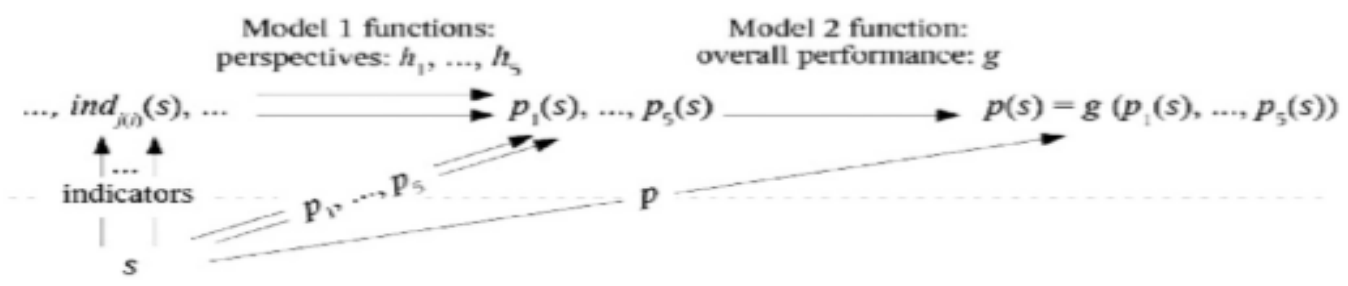

Figure 1: Representation of the Performance Measurement System (Lazzarotti et al., 2011)

Further, Hannon et al. (2015) provided a simple formula to evaluate the R\&D performance by emphasizing on the finance side of performance. The formula can be seen in the Figure 2.

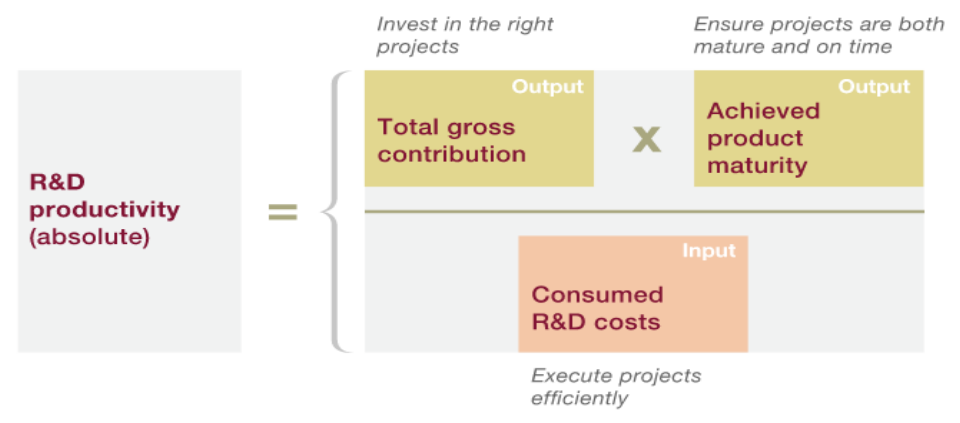

Figure 2: A single Equation for the Performance Measurement of R\&D Activities

(Hannon et al., 2015) 
Another well-known R\&D PMS is technology value pyramid that enables companies to see all factors related to the R\&D activities hierarchically consists of five different factors shown in Figure 3. This approach is similar to the performance pyramid with the aspect of demonstrating all factors related to the evaluated activities (Parish, 1998).

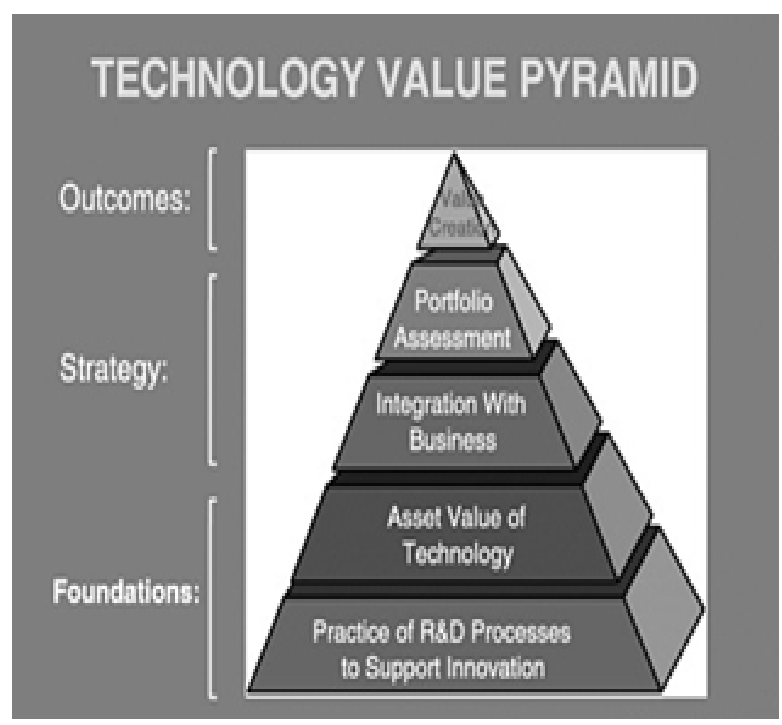

Figure 3: Technology Value Pyramid

(National Research Council,2003)

Throughout the history, some scholars have studied the performance of R\&D at a sectoral level. For instance, Tsai and Wang (2004) analyzed the impact of R\&D on the firm performance in the Taiwan's electronics sector by using a model based on the extended Cobb-Douglas production function. Further, Jankowski et al. (2005) conducted a study focusing on measuring R\&D performance in service sectors such as telecommunications, financial services, and system integration services sectors. However, this research was mostly an analysis on the current situation of the $R \& D$ performance in service sectors rather than suggesting a performance measurement system and formula for the R\&D activities in the service sectors. Moreover, another model conducted by Tian (2013) focused on the performance measurement of R\&D activities in the SWS by separating the software world into three groups as system software, application software and service software companies and tried to compare R\&D performance of these different types of software companies by using DEA model. The model selects some KPIs such as the number of employees, capital expenditures as inputs; the number 
of authorized patents, sales income as outputs. Nevertheless, this model does not suggest software related KPIs for the measurement of the R\&D performance in the SWS.

As the literature shows, the studies generally evaluate R\&D performance without specializing into software sector and even a significant part of them are not designed for any specific sector. However, a fruitful PMS designed for R\&D activities should consider the sectoral necessities as every sector has its own features and requirements. Among the studies focusing on the R\&D performance of SWS particularly, there is not such a study which suggests software related KPIs as Bremser and Barsky (2004) suggested for the performance measurement of the whole R\&D. Therefore, this study aims to create a PMS for the R\&D activities in the SWS by finding the most suitable performance measurement approach for the SWS, suggesting software related KPIs and combining them with the R\&D core KPIs. Further, the study focuses on the correlations between software related KPIs and R\&D core KPIs both internally and within each other.

\section{3) METHODOLOGY}

\subsection{Research Methodology}

This paper employs exploratory sequential mixed method by firstly starting with the unstructured interviews that are categorized as qualitative data collection method and then pursuing with the quantitative data collection. Lastly, the results of this study were interpreted based on secondary in-depth interviews in order to obtain managerial comments and management approach for the newly created PMS. The research methodology of the study can be seen in Figure 4 and Figure 5 respectively. In more detail, for this study, a well-known software company has been taken as a sample to be analyzed. Firstly, a lot of unstructured interviews with the managers and engineers of this company have been conducted to examine the SWS and R\&D mechanism and select the key metrics which are needed to be evaluated to create an effective performance measurement system for the software R\&D. Afterwards, the company's yearly results related to these key metrics which were selected based on the information gathered from these unstructured interviews, from 2012 to 2016 have been collected. Under the light of all information and data, a new PMS has been designed in response to the need of R\&D performance measurement in the SWS and afterwards the results of the study were commented based on secondary in-depth interviews. 


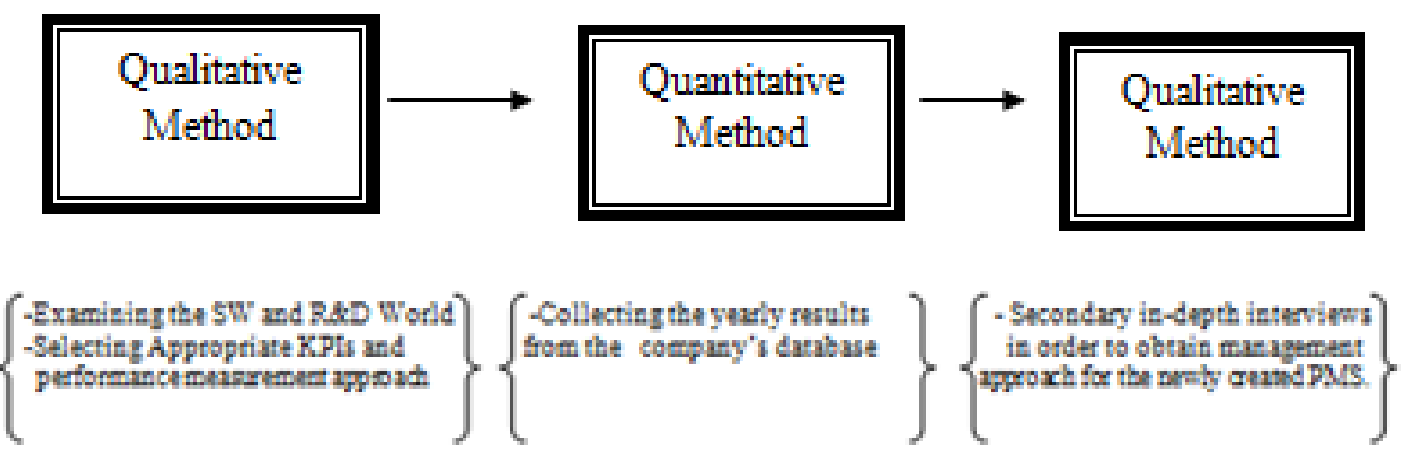

Figure 4: Research method

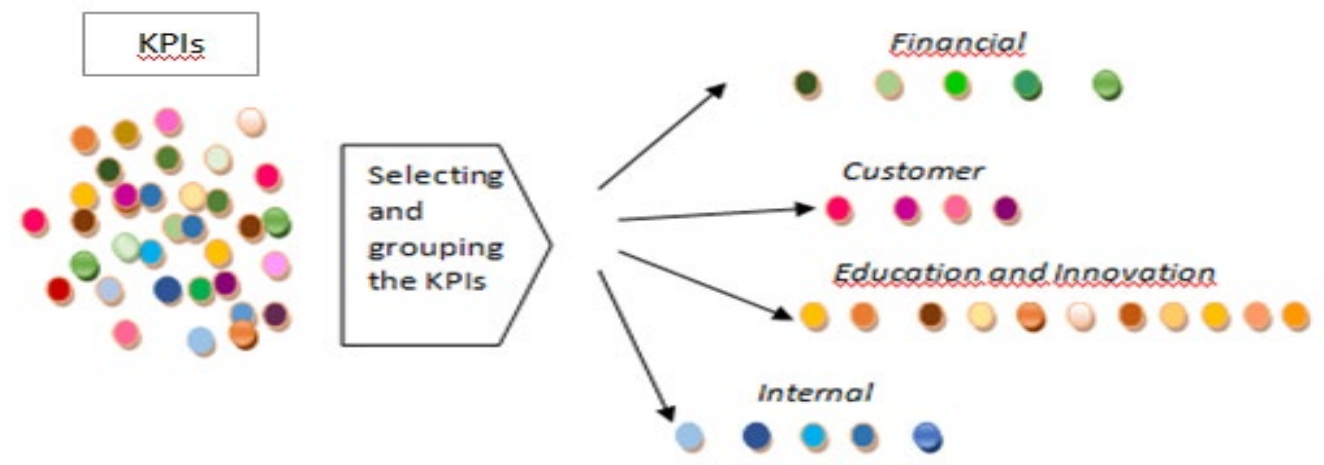

Figure 5: Illustration of selecting and grouping the KPIs

According to Bourne et al., (2003) there are three types of performance measurement design processes. These are (1) needs led, (2) audit led and (3) model led processes. The needs led approach is a top-down method in which firstly the customer, business and stakeholders' requirements are clarified and then this is taken as a basis for the improvement of performance measures. The audit led is a bottom-up method which its starting point is an audit of the current performance measures. Lastly, the model led design process is based on a prescribed theoretical model of the organization as a justification for the design of the performance measures that must be applied. Since this paper attempts to create a system which can be applied to the software industry which means it was necessary to understand the needs of the customers and the business, the needs-led approach is employed based on the needs of SWS. 
When the most-used PMS are compared, it can be seen that each performance measurement system has one better feature or worse comparing the others. BSC is the strongest model about the strategy aspect; excellence model and performance prism are good at the leadership aspect (Yuregir and Nakıboglu, 2007). Performance pyramid has the strength to integrate companies' objectives with daily operational measures. However, every model has some shortages. For instance, excellence model is so much detailed and it is hard to implement, and it takes so much time to apply. Balanced scorecard generally ignores the stakeholder perspective, performance prism does not give importance to innovation side (Yuregir and Nakiboglu, 2007) and performance prism does not give any mechanism to choose right KPIs (Striteska and Spickova, 2012). Hence, this paper selects BSC as the PMF of this research because of its comparison within other multi-dimensional PMSs. The detailed comparison can be seen in Table 2. The Table 2 shows that the most comprehensive PMFs are the excellence model and BSC. However, as the excellence model has a more complex structure, it is harder to apply than BSC. On the other hand, Performance Prism and Pyramid lack of focus on innovation and education sides, which are essential to R\&D.

Table 2: Comparison of Excellence Model, Balanced Scorecard and Performance Prism (Modified from: Yuregir and Nakıboglu, 2007) 


\begin{tabular}{|c|c|c|c|c|}
\hline Criteria & $\begin{array}{l}\text { Excellence } \\
\text { Model }\end{array}$ & $\begin{array}{l}\text { Balanced } \\
\text { Scorecard }\end{array}$ & $\begin{array}{l}\text { Performance } \\
\text { Prism }\end{array}$ & Performance Pyramid \\
\hline Focus & Quality & Customer & Stakeholders & Corporate objectives \\
\hline Strategy & $\mathrm{X}$ & $\mathrm{XX}$ & $\mathrm{X}$ & $\mathrm{X}$ \\
\hline Process & $\mathrm{XX}$ & $\mathrm{XX}$ & $\mathrm{XX}$ & $\mathrm{XX}$ \\
\hline Output & $\mathrm{XX}$ & $\mathrm{XX}$ & & $\mathrm{X}$ \\
\hline Abilities & $\mathrm{X}$ & $\mathrm{X}$ & $\mathrm{XX}$ & $X$ \\
\hline Leadership & $\mathrm{XX}$ & & & \\
\hline $\begin{array}{l}\text { Stakeholder } \\
\text { Participation }\end{array}$ & $\mathrm{X}$ & & $\mathrm{X}$ & $\mathrm{X}$ \\
\hline Stakeholder & $\mathrm{YY}$ & $\mathrm{Y}$ & YYY & $\mathrm{X}$ \\
\hline Workers & $\begin{array}{l}x x \\
X\end{array}$ & $\begin{array}{l}X \\
X\end{array}$ & $\begin{array}{l}x \times x \\
X\end{array}$ & $X$ \\
\hline Customer & $\mathrm{X}$ & $\mathrm{X}$ & $\mathrm{X}$ & X \\
\hline $\begin{array}{l}\text { Shareholders } \\
\text { Suppliers }\end{array}$ & $\begin{array}{l}\mathrm{X} \\
\mathrm{X}\end{array}$ & X & $\begin{array}{l}X \\
X\end{array}$ & \\
\hline Banks & $\begin{array}{l}\Lambda \\
X\end{array}$ & & $\begin{array}{l}A \\
X\end{array}$ & \\
\hline Society & $X$ & & $X$ & \\
\hline Government & $\mathrm{X}$ & & $\mathrm{X}$ & \\
\hline Technology & $\mathrm{X}$ & $\mathrm{X}$ & $\mathrm{X}$ & \\
\hline Innovation & $\mathrm{X}$ & $\mathrm{X}$ & & \\
\hline Education & $\mathrm{X}$ & $\mathrm{X}$ & & \\
\hline Easiness to apply & & $\mathrm{X}$ & & \\
\hline
\end{tabular}

\subsection{Creating the Performance Measurement System and Formula}

To create the performance measurement system, selected KPIs are categorized into four groups:

1) Financial group which focuses on the financial situation of the $R \& D$ activities.

2) Customer group which includes the KPIs directly affecting the customer behavior and satisfaction and is also directly affected by the customers. 3) Education and innovation group which covers the KPIs that are related to improvement of the $R \& D$ innovation and education related activities 4) Internal process group which includes the KPIs that show the internal capability of the R\&D activities as taking the basis of 'Balanced Scorecard Framework. 
In order to create an effective performance measurement system, this study analyzes the performance into two phases. The first phase is the 'Growth' phase that indicates how the company has evolved comparing to one year before, whether its performance has increased, decreased, or stayed stable. The second phase is the 'Goal Achievement' phase that compares the targeted performance with the actual achievement of that targeted performance. The general formula of two phases is same as shown in Table 3 . Table 3 shows that

1) Every KPI has its own score ( How they are scored will be shown later on )

2) Every KPI has its own weight

3) Each KPI's score is multiplied by its own weight in order to find its weighted score.

4) The total score is found by adding the all weighted scores.

Table 3: General Formula

Formula $=\mathrm{W}_{1} \times \mathrm{K}_{1}+\mathrm{W}_{2} \times \mathrm{K}_{2}+\mathrm{W}_{3} \times \mathrm{K}_{3}+\mathrm{W}_{4} \times \mathrm{K}_{4}+\ldots \ldots \ldots \ldots+\mathrm{W}_{26} \times \mathrm{K}_{26}$ $K_{n}=$ Score of $K P I_{n}$

$W_{n}=$ Weight of $K_{n}$

Further, every KPI has its own formula and explanations. It should be kept in mind that these own formulas differ from the 'Growth' part to 'Goal Achievement part. Table 4 shows the grouping of the KPIs in four different perspectives which are named as finacial side, customer side, innovation \&education side and internal process side. KPIs related to the finance such as turnover or r\&d expenditures per each employee are grouped under the financial side. Customer side includes the KPIs which are either input or output of customer satisfaction and retention. Education and innovation side consists of the KPIs that either affect the success or affected by the success of the R\&D activities in the areas of education and innovation.Lastly, all KPIs which are spesific to the internal process of the software sector are positioned under the internal process side.

Table 4: The grouping of the KPIs in four different perspectives

\section{Financial Side}




\begin{tabular}{|l|l|}
\hline K1 & Percentage Revenue from new products \\
\hline K2 & R\&D expenditures per each employee \\
\hline K3 & Turnover \\
\hline K4 & Percentage of R\&D export rate \\
\hline K5 & Percentage change of R\&D export \\
\hline \multicolumn{2}{|l|}{ Customer Side } \\
\hline K6 & Due Date Responsiveness(BC) \\
\hline K7 & Due Date Responsiveness(MJ) \\
\hline K8 & Case Quality \\
\hline K9 & Rate of Registered Order Change \\
\hline \multicolumn{2}{|l|}{ Education and Innovation Side } \\
\hline K10 & Intensity of R\&D Employees with Ph.D. and Master Degree \\
\hline K11 & Intensity of projects with University-Industrial Cooperation (public funded) \\
\hline K12 & Intensity of projects without University-Industrial Cooperation (public funded) \\
\hline K13 & Intensity of projects with University-Industrial Cooperation (without public \\
& funded) \\
\hline K14 & Intensity of registered international patents \\
\hline K15 & Intensity of registered national patents \\
\hline K16 & Intensity of applied international patents \\
\hline K17 & Intensity of applied national patents \\
\hline K18 & Number of Conference/Fair Participation \\
\hline K19 & Number of Received Awards \\
\hline K20 & Number of training hours within the R\&D activities \\
\hline K21 & Intensity of scientific article and publications \\
\hline K22 & Intensity of registered brand \\
\hline & Tesolution per engineer \\
\hline K23 & Time Per case (NPD)(days) \\
\hline K24 & Time per case (PD)(days) \\
\hline K25 & \\
\hline
\end{tabular}

\subsubsection{Explanations/formulations of all the KPIs}

\section{Financial Side}

K1-Percentage Revenue from new products:

Revenue From New Products

Total Revenue 
K2-R\&D expenditures per each employee:

Total R\&D Expenditures

Number of Employees

K3-Turnover: This KPI shows the overall turnover of the company

K4-Percentage change of R\&D export rate:

Revenue from R\&D Export

Revenue from R\&D Export+ Import

K5-Percentage change of R\&D export:

$$
\frac{\text { Export Rate(T) }- \text { Export Rate }(\mathrm{T}-1)}{\text { Export Rate }(\mathrm{T}-1)} \times 100
$$

\section{Customer Side}

K6-Due Date Responsiveness (BC): This KPI implies the response percentage of the business critical cases on time. Business critical cases are very critical cases that can cause a penalty cost if they are not solved on time. Therefore, the response rate should be very high in order to satisfy the customers and not to cause to any additional cost. In the SWS contrary to the other sectors, there is not a hand-held-visible product. Hence, it is not possible to change one out-ofservice product with another one from the inventory. The problematic products/softwares should be solved by the R\&D engineers and therefore due-date responsiveness is very crucial in the SWS.

K7-Due Date Responsiveness (MJ): This KPI has the same meaning with the KPI 6. The only difference comes from the urgency of the cases. Major cases (MJ) are less urgent comparing the Business Critical Cases; they do not cause any penalty cost, but still, these cases are so much important for the customer satisfaction. Being responsive to the cases determines the customer retention and since the most important element of the SWS likewise the other sectors is the customers, due date responsiveness has a high importance for the customer side.

K8-Case Quality: This KPI implies how well an software case after it is fixed is working. This KPI questions whether it is working according to the standards or in the way customer wants. 
K9- Change of Registered Order Rate; This KPI shows the change of registered ordered comparing to one year before. From this KPI the satisfaction and retention of the customers can be understood.

\section{Education and Innovation Side}

K10- Intensity of R\&D Employees with Ph.D. and Master Degree:

Number of R\&D Employees with Ph.D and Master Degree

X 100

Number of Total R\&D Employees

K11- Intensity of projects with University-Industrial Cooperation (public funded):

Number of projects with University-Industrial Cooperation (public funded) $\quad$ X 100

Number of Total Projects

K12- Intensity of projects without University-Industrial Cooperation (public funded):

Number of projects without University-Industrial Cooperation (public funded)

Number of Total Projects

K13- Intensity of projects with University-Industrial Cooperation (without public funded)

Number of projects with University-Industrial Cooperation(without public funded)

Total Number of Projects

K14- Intensity of registered international patents 
Number of registered international patents

Number of R\&D Employees

K15- Intensity of registered national patents:

Intensity of registered national patents

Number of R\&D Employees

K16- Intensity of applied international patents:

Number of applied international patents

Number of R\&D Employees

K17- Intensity of applied national patents

Number of applied national Patents

Number of R\&D Employees

K18-Number of Conference /Fair Participation

K19- Number of Received Awards

K20-Number of training hours within the R\&D activities

K21- Intensity of scientific article and publications:

Number of scientific article and publications

Number of R\&D Employees

K22- Intensity of registered brand

Number of Registered Brand

Number of R\&D Employees 


\section{Internal Process Side}

K23-Resolution per engineer: This KPI implies how many software related problem is solved by one R\&D engineer. This KPI shows the effectiveness of the R\&D engineers.

K24-Time Tracking Utilization: This KPI shows the rate of total utilization on cases of the R\&D engineers. The target of this KPI is selected as $70 \%$ by our sample software company. Results which exceed this target or which remain below of this target are not desired. For this KPI, the closer to target performance is the better

K25-Time per case (NPD): In an software, some cases can be solved only with configuration. This KPI shows how many days are spent on one case which is solved by configuration. These cases need less time comparing the other cases which are needed more detailed analysis.

K26-Time per case (PD): As it is mentioned earlier, in an software, some cases can be solved only with configuration. However, some need more detailed analysis. The ones which cannot be solved by the configuration need to be solved by the design part of the R\&D department. In the design part, there are architects who write the codes from the beginning rather than changing the order of codes or making configuration. Those cases require more time comparing the others. This KPI is another important KPI which shows how many days are spent on one case which is solved by design.

\subsubsection{Selecting the most appropriate KPIs related to R\&D activities in the SWS}

After conducting the preliminary interview with R\&D managers, it was found that the most important element of the SWS is fulfilling customers' requirements as they go along with the project or product development process. R\&D process in this sector shows that there are required changes generally result from three reasons as shown below:

1) Software related unsolved problems such as bugs in the system

2) The responsiveness of software is slow

3) The quality of software is not sufficient.

By looking at these reasons, the necessary KPIs to measure the performance of the which cause to these reasons are explained as follows: 
Due Date Responsiveness for Business Critical and Major Cases

These two KPIs are very crucial since there is not a hand-held-visible product in the SWS contrary to the other sectors. Hence, it is not possible to change one out-of-service product with another one from the inventory. The problematic products/softwares should be solved by the R\&D engineers and therefore due-date responsiveness has a high importance for the SWS. If the response rate does not become satisfying enough, customer loss will be inevitable.

Time Per case for PD and NPD

Time per case is examined in two parts. The first one (PD) is time per case for the products which are not solved together with the design part; the latter (NPD) is for the ones which are solved with the only configuration and without the design part. The aim of the software companies should be decreasing time per case as much as possible by protecting or even improving the current case quality. The reason behind taking time per case NPD and PD separately is that their targets are different and PD also shows the effectiveness of the design part which is very crucial for the software companies.

\section{Resolution per Engineer}

In the software sector, there is a high emphasis on the importance of the R\&D engineers. This is because software issues need a deep analysis and qualified engineers so that they can be solved and run without any problem. Hence, when creating a PMS into software R\&D activities, the effectiveness of the R\&D engineers should be evaluated carefully. Here, this KPI shows the effectiveness of the R\&D engineers by looking at how many issues are solved by one $R \& D$ engineer.

\section{Time Tracking Utilization}

The reason why this KPI should be put into this performance measurement system is to show the importance of the balance between time spent on issues/developing an software and time spent on other activities such as writing patents, or participating trainings. Since R\&D workers cannot be successful and satisfied enough if they only work on the cases. The high speed of the software development requires more trainings and educational activities for the $R \& D$ employees. This is why this KPI's result should not be higher than one targeted rate (here our company chose this rate as $70 \%$ ). Results above or below of this target are not desired. The 
logic behind this KPI is that the closer to target performance is the better. For example, both $100 \%$ utilization and $40 \%$ utilization implies unsuccessfulness. In the other time periods, R\&D workers should participate training, try to write/read patents, articles and in other terms try to do other activities related to the R\&D and follow the software world.

\section{Quality}

When it comes to the quality part of an software, there are two points of views for evaluating software. The first one is the quality of an software case which comes from the customers, whether the software can run without any issue after a problem related to that software when the problem of the customer is solved or not. The second one is the project quality. Project quality also should be viewed with different phases. The first one is the criteria directly related to software such as the rate of critical defects found in the softwares, the effectiveness of the tests done to softwares. The latter is the criteria that are about time and budget side of the projects. Unfortunately, one of this research limitations is to analyze project quality due to lack of data and hence the inability to verification. This situation will be analyzed in details in the limitation part of the study, and necessary recommendations will be given for the further studies. However, with the KPI of 'Case quality' that is K8, the first phase of the quality parts can be analyzed as required.

\subsubsection{Growth Rate and Goal Achievement Calculation}

Growth rate and goal achievement general formulas are given in Table 5 and Table 6 respectively. There are some KPIs which do not fit these general formulas and hence they have their own separate formulas. These exceptional KPIs and their formulas are also given in Table 5 and 6. 
Table 5: Growth Rate Calculation

\begin{tabular}{|c|c|}
\hline $\begin{array}{c}\text { General Growth Rate } \\
\text { Calculation }\end{array}$ & Formula / Reason \\
\hline $\begin{array}{c}\text { Calculation for K5 } \\
\text { and K9 }\end{array}$ & $\begin{array}{c}\text { These KPIs' results are taken directly as the growth rate Since these KPIs already } \\
\text { show the change by comparing the current results with the results of one year before. }\end{array}$ \\
\hline $\begin{array}{c}\text { Growth Rate } \\
\text { Growth Rate } \\
\text { Calculation for K24 }\end{array}$ & Absolute[Result (T-1)-Target Performance]-Absolute[Result(T)-TargetPerformance)] \\
\hline $\begin{array}{c}\text { GrowthRate } \\
\text { Calculation for K25 } \\
\text { and K26 }\end{array}$ & - ((Result (T)-Result (T-1)) \\
\hline
\end{tabular}

Table 6: Goal Achievement Calculation

\begin{tabular}{|c|c|c|}
\hline & Formulation / Reason & \\
\hline $\begin{array}{l}\text { General } \\
\text { Goal Achievement } \\
\text { Calculation }\end{array}$ & $\frac{\text { Result }(\mathrm{T})}{\text { Targeted Performance(T) }}$ & X 100 \\
\hline $\begin{array}{l}\text { Goal Achievement } \\
\text { Calculation for K24 }\end{array}$ & Absolute [Result $(\mathrm{T})$ - Targeted Performance $(\mathrm{T})]$ & \\
\hline $\begin{array}{l}\text { Goal Achievement } \\
\text { Calculation for K25 } \\
\text { and K26 }\end{array}$ & $\begin{array}{c}\text { Targeted Performance(T) } \\
\text { Result }(\mathrm{T})\end{array}$ & X 100 \\
\hline
\end{tabular}

A score is given to each KPI according to the result of each KPI's growth and goal achievement

calculation. Growth and goal achievement part have separate scoring systems that are given in the following tables. 
The table 7 and 8 show that maximum point is 7,5 and minimum point is $-7,5$ for all KPIs according to the growth scoring system .

Table 7 is the general growth scoring system for all the KPIs excluding the KPI 24. As it can be seen in the Table 7, the scores change between $-7,5$ and $+7,5$ according to the its growth or reduction ratio. If there is no growth or reduction, it is pointed as 0 .

Table 7: General Growth Scoring System

\begin{tabular}{|c|c|c|c|}
\hline $\mathrm{X}<=-145 \%$ & $-7,5$ & $0 \%<\mathrm{X}<=5 \%$ & 0,25 \\
\hline$-145 \%<\mathrm{X}<=-140 \%$ & $-7,25$ & $5 \%<X<=10 \%$ & 0,5 \\
\hline$-140 \%<\mathrm{X}<=-135 \%$ & -7 & $10 \%<X<=15 \%$ & 0,75 \\
\hline$-135 \%<\mathrm{X}<=-130 \%$ & $-6,75$ & $15 \%<\mathrm{X}<=20 \%$ & 1 \\
\hline$-130 \%<\mathrm{X}<=-125 \%$ & $-6,5$ & $20 \%<X<=25 \%$ & 1,25 \\
\hline$-125 \%<\mathrm{X}<=-120 \%$ & $-6,25$ & $25 \%<X<=30 \%$ & 1,5 \\
\hline$-120 \%<\mathrm{X}<=-115 \%$ & -6 & $30 \%<X<=35 \%$ & 1,75 \\
\hline$-115 \%<\mathrm{X}<=-110 \%$ & $-5,75$ & $35 \%<\mathrm{X}<=40 \%$ & 2 \\
\hline$-110 \%<\mathrm{X}<=-105 \%$ & $-5,5$ & $40 \%<\mathrm{X}<=45 \%$ & 2,25 \\
\hline$-105 \%<\mathrm{X}<=-100 \%$ & $-5,25$ & $45 \%<\mathrm{X}<=50 \%$ & 2,5 \\
\hline$-100 \%<X<=-95 \%$ & -5 & $50 \%<X<=55 \%$ & 2,75 \\
\hline$-95 \%<X<=-90 \%$ & $-4,75$ & $55 \%<\mathrm{X}<=60 \%$ & 3 \\
\hline$-90 \%<\mathrm{X}<=-85 \%$ & $-4,5$ & $60 \%<\mathrm{X}<=65 \%$ & 3,25 \\
\hline$-85 \%<\mathrm{X}<=-80 \%$ & $-4,25$ & $65 \%<X<=70 \%$ & 3,5 \\
\hline$-80 \%<X<=-75 \%$ & -4 & $70 \%<X<=75 \%$ & 3,75 \\
\hline$-75 \%<X<=-70 \%$ & $-3,75$ & $75 \%<\mathrm{X}<=80 \%$ & 4 \\
\hline$-70 \%<X<=-65 \%$ & $-3,5$ & $80 \%<\mathrm{X}<=85 \%$ & 4,25 \\
\hline$-65 \%<X<=-60 \%$ & $-3,25$ & $85 \%<X<=90 \%$ & 4,5 \\
\hline$-60 \%<X<=-55 \%$ & -3 & $90 \%<X<=95 \%$ & 4,75 \\
\hline$-55 \%<X<=-50 \%$ & $-2,75$ & $95 \%<X<=100 \%$ & 5 \\
\hline$-50 \%<X<=-45 \%$ & $-2,5$ & $100 \%<\mathrm{X}<=105 \%$ & 5,25 \\
\hline$-45 \%<\mathrm{X}<=-40 \%$ & $-2,25$ & $105 \%<\mathrm{X}<=110 \%$ & 5,5 \\
\hline$-40 \%<X<=-35 \%$ & -2 & $110 \%<\mathrm{X}<=115 \%$ & 5,75 \\
\hline$-35 \%<X<=-30 \%$ & $-1,75$ & $115 \%<\mathrm{X}<=120 \%$ & 6 \\
\hline$-30 \%<X<=-25 \%$ & $-1,5$ & $120 \%<\mathrm{X}<=125 \%$ & 6,25 \\
\hline$-25 \%<X<=-20 \%$ & $-1,25$ & $125 \%<\mathrm{X}<=130 \%$ & 6,5 \\
\hline$-20 \%<X<=-15 \%$ & -1 & $130 \%<\mathrm{X}<=135 \%$ & 6,75 \\
\hline$-15 \%<X<=-10 \%$ & $-0,75$ & $135 \%<\mathrm{X}<=140 \%$ & 7 \\
\hline$-10 \%<X<=-5 \%$ & $-0,5$ & $140 \%<\mathrm{X}<=145 \%$ & 7,25 \\
\hline$-5 \%<X<=0 \%$ & $-0,25$ & $145 \%<\mathrm{X}$ & 7,5 \\
\hline $0=X$ & 0 & & \\
\hline
\end{tabular}


This scoring system can be applied to any KPI except the KPI K24. That is because, for that KPI even one percentage of change is important, therefore this K24's growth score is calculated in another way. This calculation can be seen in the Table 8 . Table 8 indicates that if the the deviation from year (T-1) to (T )from the target of K24 increases, KPI24 is pointed between $-7,5$ and 0 showing that there is a reduction. In contrast if the deviation from year (T-1) to (T )from the target of K24 decreases, KPI24 is pointed between 0 and 7.5 showing that there is a growth. If there is no change in the deviations from year (T-1) to (T), then the KPI24 is pointed as 0 .

Table 8: K24 Growth Scoring System

\begin{tabular}{|c|c|c|c|}
\hline$X<=-14 \%$ & $-7,5$ & $0<\mathrm{X}<=1 \%$ & 0,5 \\
\hline$-14 \%<\mathrm{X}<=-13 \%$ & -7 & $0<\mathrm{X}<=2 \%$ & 1 \\
\hline$-13 \%<X<=-12 \%$ & $-6,5$ & $0<\mathrm{X}<=3 \%$ & 1,5 \\
\hline$-12 \%<\mathrm{X}<=-11 \%$ & -6 & $0<\mathrm{X}<=4 \%$ & 2 \\
\hline$-11 \%<\mathrm{X}<=-10 \%$ & $-5,5$ & $0<\mathrm{X}<=5 \%$ & 2,5 \\
\hline$-10 \%<X<=-9 \%$ & -5 & $0<\mathrm{X}<=6 \%$ & 3 \\
\hline$-9 \%<X<=-8 \%$ & $-4,5$ & $0<X<=7 \%$ & 3,5 \\
\hline$-8 \%<\mathrm{X}<=-7 \%$ & -4 , & $0<\mathrm{X}<=8 \%$ & 4 \\
\hline$-7 \%<X<=-6 \%$ & $-3,5$ & $0<\mathrm{X}<=9 \%$ & 4,5 \\
\hline$-6 \%<X<=-5 \%$ &,- 3 & $0<\mathrm{X}<=10 \%$ & 5 \\
\hline$-5 \%<X<=-4 \%$ & $-2,5$ & $0<\mathrm{X}<=11 \%$ & 5,5 \\
\hline$-4 \%<X<=-3 \%$ & -2 & $0<X<=12 \%$ & 6 \\
\hline$-3 \%<X<=-2 \%$ & $-1,5$ & $0<\mathrm{X}<=13 \%$ & 6,5 \\
\hline$-2 \%<X<=-1 \%$ & -1 & $0<\mathrm{X}<=14 \%$ & 7 \\
\hline
\end{tabular}




\begin{tabular}{|c|c|c|c|}
\hline$-1 \%<\mathrm{X}<0 \%$ & $-0,5$ & $14 \%<\mathrm{X}$ & 7,5 \\
& & & \\
\hline $\mathrm{X}=0 \%$ & 0 & & \\
\hline
\end{tabular}

Regarding the goal achievement scoring system, Table 9 shows that when the goal achievement is 0 , the point given becomes 0 as well. Goal achievement point increases as 0,25 point in every $\% 5$ increase of the goal achievement .

Table 9: General Goal Achievement Scoring System

\begin{tabular}{|c|c|c|c|}
\hline $\mathrm{X}=0 \%$ & 0 & $75 \%<\mathrm{X}<=80 \%$ & 4 \\
\hline $0 \%<\mathrm{X}<=5 \%$ & 0,25 & $80 \%<\mathrm{X}<=85 \%$ & 4,25 \\
\hline $5 \%<\mathrm{X}<=10 \%$ & 0,5 & $85 \%<X<=90 \%$ & 4,5 \\
\hline $10 \%<\mathrm{X}<=15 \%$ & 0,75 & $90 \%<X<=95 \%$ & 4,75 \\
\hline $15 \%<\mathrm{X}<=20 \%$ & 1 & $95 \%<\mathrm{X}<=100 \%$ & 5 \\
\hline $20 \%<\mathrm{X}<=25 \%$ & 1,25 & $100 \%<\mathrm{X}<=105 \%$ & 5,25 \\
\hline $25 \%<\mathrm{X}<=30 \%$ & 1,5 & $105 \%<\mathrm{X}<=110 \%$ & 5,5 \\
\hline $30 \%<\mathrm{X}<=35 \%$ & 1,75 & $110 \%<\mathrm{X}<=115 \%$ & 5,75 \\
\hline $35 \%<\mathrm{X}<=40 \%$ & 2 & $115 \%<\mathrm{X}<=120 \%$ & 6 \\
\hline $40 \%<\mathrm{X}<=45 \%$ & 2,25 & $120 \%<\mathrm{X}<=125 \%$ & 6,25 \\
\hline $45 \%<\mathrm{X}<=50 \%$ & 2,5 & $125 \%<\mathrm{X}<=130 \%$ & 6,5 \\
\hline $50 \%<X<=55 \%$ & 2,75 & $130 \%<\mathrm{X}<=135 \%$ & 6,75 \\
\hline $55 \%<X<=60 \%$ & 3 & $135 \%<\mathrm{X}<=140 \%$ & 7 \\
\hline $60 \%<X<=65 \%$ & 3,25 & $140 \%<\mathrm{X}<=145 \%$ & 7,25 \\
\hline $65 \%<X<=70 \%$ & 3,5 & $145 \%<X$ & 7,5 \\
\hline $70 \%<X<=75 \%$ & 3,75 & & \\
\hline
\end{tabular}


Similar to the growth scoring for the KPI 24, KPI 24 has its own goal achievement scoring system as the general goal achievement scoring system does not make sense for this KPI .

Since the goal achievement formulation for the KPI 24 is as follows: Absolute [Result (T) Targeted Performance $(\mathrm{T})$ ], the desired outcome becomes 0 meaning that there is no deviation from the target. Therefore, as it can been seen in the Table 10, since the result of $0 \%$ implies a better goal achievement, it is pointed with the highest score which is 7,5. Every $\% 1$ deviation decreases the goal achievement score of $\mathrm{K} 24$ with $-0,25$ point.

Table 10: Goal Achievement Scoring System for KPI 24

\begin{tabular}{|l|l|l|l|}
\hline $\mathrm{X}=0 \%$ & 7,5 & $15 \%<\mathrm{X}<=16 \%$ & 3,5 \\
\hline $0 \%<\mathrm{X}<=1 \%$ & 7,25 & $16 \%<\mathrm{X}<=17 \%$ & 3,25 \\
\hline $1 \%<\mathrm{X}<=2 \%$ & 7 & $17 \%<\mathrm{X}<=18 \%$ & 3 \\
\hline $2 \%<\mathrm{X}<=3 \%$ & 6,75 & $18 \%<\mathrm{X}<=19 \%$ & 2,75 \\
\hline $3 \%<\mathrm{X}<=4 \%$ & 6,5 & $19 \%<\mathrm{X}<=20 \%$ & 2,5 \\
\hline $4 \%<\mathrm{X}<=5 \%$ & 6,25 & $20 \%<\mathrm{X}<=21 \%$ & 2,25 \\
\hline $5 \%<\mathrm{X}<=6 \%$ & 6 & $21 \%<\mathrm{X}<=22 \%$ & 2 \\
\hline $6 \%<\mathrm{X}<=7 \%$ & 5,75 & $22 \%<\mathrm{X}<=23 \%$ & 1,75 \\
\hline $7 \%<\mathrm{X}<=8 \%$ & 5,5 & $23 \%<\mathrm{X}<=24 \%$ & 1,5 \\
\hline $8 \%<\mathrm{X}<=9 \%$ & 5,25 & $24 \%<\mathrm{X}<=25 \%$ & 1,25 \\
\hline $9 \%<\mathrm{X}<=10 \%$ & 5 & $25 \%<\mathrm{X}<=26 \%$ & 1 \\
\hline $10 \%<\mathrm{X}<=11 \%$ & 4,75 & $26 \%<\mathrm{X}<=27 \%$ & 0,75 \\
\hline $11 \%<\mathrm{X}<=12 \%$ & 4,5 & $27 \%<\mathrm{X}<=28 \%$ & 0,5 \\
\hline $12 \%<\mathrm{X}<=13 \%$ & 4,25 & $28 \%<\mathrm{X}<=29 \%$ & 0,25 \\
\hline $13 \%<\mathrm{X}<=14 \%$ & 4 & $29 \%<\mathrm{X}$ & 0 \\
\hline $14 \%<\mathrm{X}<=15 \%$ & 3,75 & & \\
\hline & & & \\
\hline & & & \\
\hline & & & \\
\hline
\end{tabular}

In addition, scores are weighted and these weights can be found in the Table 11. Table 11 indicates that KPIs grouped under financial side have more importance to the company 
comparing the KPIs in the other group. This is followed by KPIs in customer side, internal process side and education \& innovation side respectively on the base of KPI. Since every KPI has its own weight, the growth rate and goal achievement scores will be multiplied by the each KPI's own weight. Hence, two KPIs with the same score can affect the total weighted scores differently. This results from the importance of the KPIs which they express to the company.

Table 11: Weight of each KPI

\begin{tabular}{|l|l|l|l|}
\hline Finance (40\%) & & K13 & $1,0 \%$ \\
\hline K1 & $7 \%$ & K14 & $2,5 \%$ \\
\hline K2 & $7 \%$ & K15 & $2,0 \%$ \\
\hline K3 & $10 \%$ & K16 & $4,5 \%$ \\
\hline K4 & $8,0 \%$ & K17 & $4,0 \%$ \\
\hline K5 & $8,0 \%$ & K18 & $2,0 \%$ \\
\hline Customer Side (22\%) & & K19 & $1,5 \%$ \\
\hline K6 & $4,75 \%$ & K20 & $2,0 \%$ \\
\hline K7 & $4,25 \%$ & K2 1 & $0,5 \%$ \\
\hline K8 & $6,25 \%$ & K22 & $0,5 \%$ \\
\hline K9 & $6,75 \%$ & Internal Process & \\
\hline $\begin{array}{l}\text { Education and Innovation } \\
\text { Side (25\%) }\end{array}$ & & Side (13\%) & \\
\hline K10 & & K23 & $3,3 \%$ \\
\hline K11 & $1,9 \%$ & K24 & \\
\hline K12 & $1,4 \%$ & K25 & $3,2 \%$ \\
\hline & $1,2 \%$ & K26 & $3,2 \%$ \\
\hline
\end{tabular}

\section{4) RESULTS AND DISCUSSION}

In this section, the new PMS for SWS is used by obtaining data from the software company from 2012 until 2016 as shown in Table 12. According to the results and targets of the company, the growth and goal achievement scores that can be seen in the Table 12 and 13 respectively. 
Table 12: Growth Scores

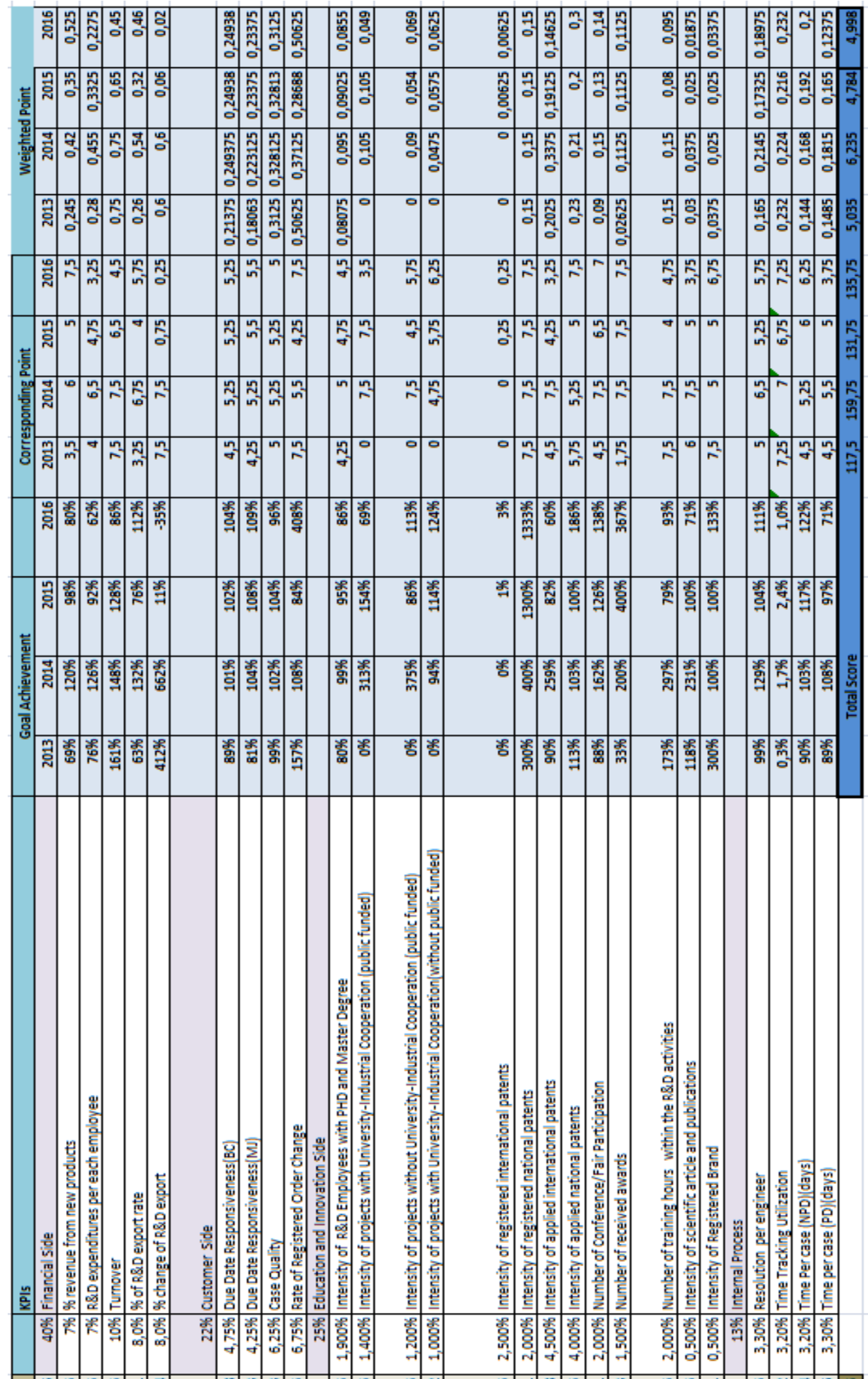



Table 13: Goal Achievement Scores

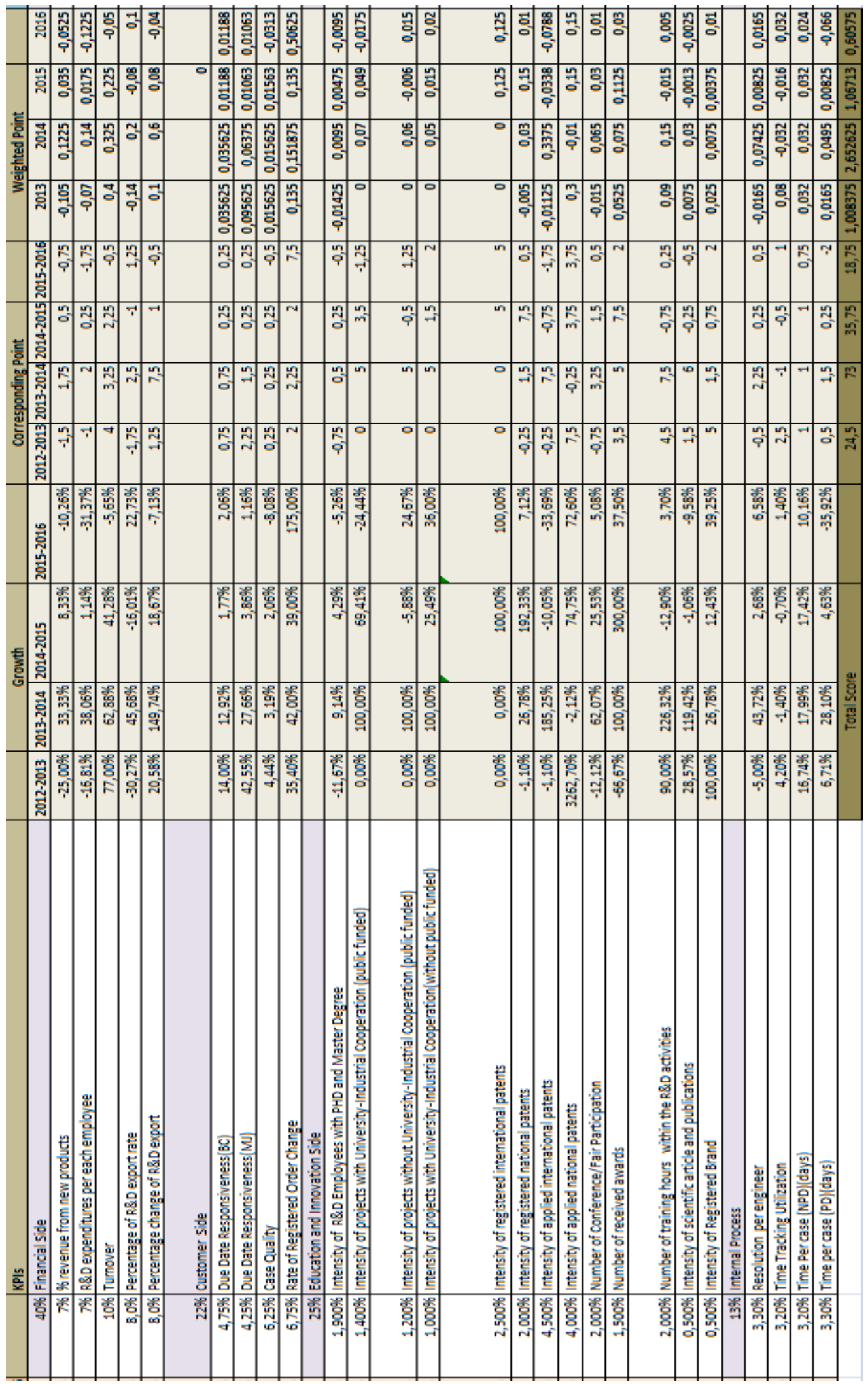


Moreover, the scores and their changes among the years are analyzed based on the follow-up in-depth interviews conducted with the managers of the company. Lastly, correlation coefficients for various combinations are determined in order to see if there are any relations between KPIs. Table 14 also shows that while software related KPIs are gathered on the customer side and internal process side, R\&D related KPIs are grouped under financial side and innovation-education side. Further, the results in Table 14 are the weighted results since the real results of the sample software company are weighted in a way that it does not to affect neither the growth nor the goal achievement score in order to protect the confidentiality of the company.

Table 14: Yearly Results and Targets 


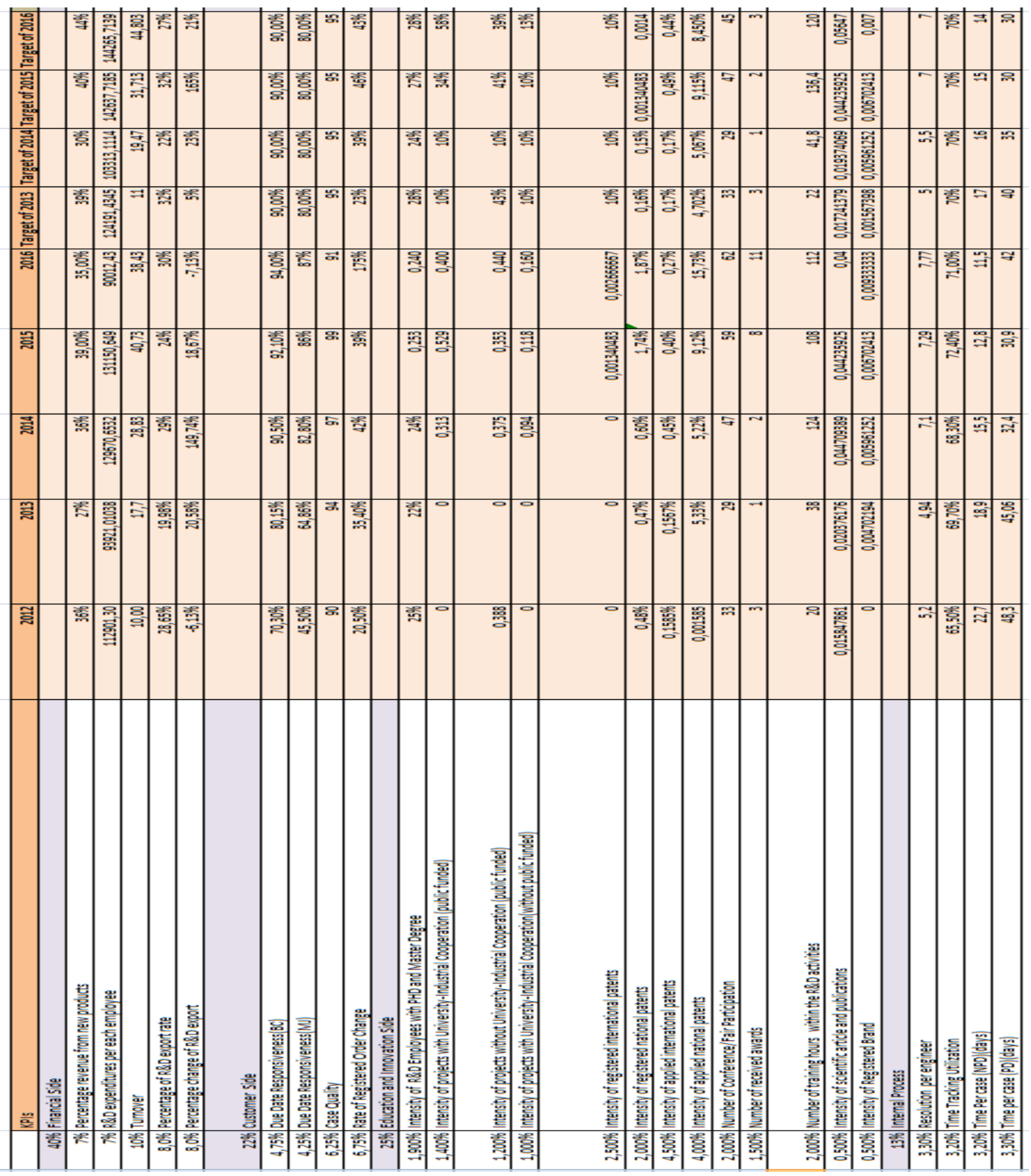

Correlation coefficients $(\mathrm{CC})$ for different combinations are calculated to see the relation between selected KPIs. The Table 15 consists of the most noteworthy results of these calculations. The results show that overall turnover has positively related with other R\&D related KPIs. For instance, turnover increases with the CC 0,48 as percentage revenue from new products increases or an increase in $R \& D$ expenditures per each employee causes an increase in turnover with the CC 0.19 . These positive CCs are the proofs of how much the 
financial situation of R\&D activities are related to the companies' overall financial results. On the other hand, it can be seen a positive correlation between intensity of R\&D employees with PHD and master degree and turnover with the CC of 0.22 . That can be commented as the increase in the quality of the employees results a visible positive change in turnover as well. As expected, another KPI which has a strong positive relation with turnover is case quality. ( $\mathrm{CC}$ is 0,53$)$. A remarkable finding here is that there is a negative correlation between intensity of R\&D employees with PHD and master degree and intensity of applied national patents with $\mathrm{CC}-0,11$. However there is a moderate positive correlation between the intensity of R\&D employees with Ph.D. and master degree and intensity of registered national patents. (CC is 0,32$)$ This result shows that although the number of applied patents decreases as the intensity of R\&D employees with Ph.D. and master degree increases; the number of registered patents increases since the quality of the patents with the intensity of R\&D employees with Ph.D. and master degree become higher. The findings of the research show that number of patents has negatively correlated with time per case PD and R\&D expenditures per each employee( $-0,32$ and $-0,31$ respectively). Even though the first negative correlation is predictable since if an employee spends more time on a case, this will lead him/her to spend less time for writing a patent; the latter result is suprising as it is expected that investing more money in R\&D staff would cause more patent application . Moreover, the $\mathrm{CC}(0,19)$ between number of patents and percentage revenue from new products is an indicative that these patents are value-added services/products. Another noticeable finding of the research is that resolution per engineer is positively correlated $(\mathrm{CC}$ is 0,36$)$ with case quality which indicates that quality of the engineers increases since case quality became better in spite of more resolution per engineer. The findings of the research show that projects with university-industrial cooperation(PUIC) affect percentage revenue from new products(PRNP) very positively with a correlation coefficient of 0,66 . This can be commented that as the number of changes of ideas increases, the success of the products increases and this leads to an increase in PRNP.The noticeable finding here is that the correlation coefficient $(0,86)$ between the intensity of public 
funded projects and PRNP is higher comparing the correlation coefficient between turnover and (PUIC). That might mean, companies focus on the projects that they allocate budget more than other projects which are funded since they do not want to take risk of loss. Moreover, the negative correlation between time per case (PD /NPD) and PRNP is expectable as spending more time on a case would result in less development and cause to receive less money from new products.(CCs are $-0,35$ and $-0,55$ respectively) Here, the noteworthy result is that the effect of spending more time on PD cases is more than the effect of NPD cases which is an indicative of the importance of PD cases requiring more deeply analysis.

Table 15: Correlation Coefficients (CC) for some important KPIs

\begin{tabular}{|c|c|}
\hline Caluulated KPIs & Correlation Coefficient \\
\hline Tumoverl Percentage revenue from new poducts & 0,48 \\
\hline Turnoverlose Qualty & 0,53 \\
\hline TumoverkRBD ejpendtures per ach employes & 0,19 \\
\hline Tumoverk Percentage of R\&D expot rate & 0,18 \\
\hline Intensity of RBD Employees with FhD and Master Degres \&Tumover & 0,22 \\
\hline Due Date Respongiveness $[\mathrm{BC}]$ \& Rate of Registered Order change & 0,58 \\
\hline Intensity of RQD Employees with FhD and Master Degree\& Intensity of registered national patents & 0,32 \\
\hline Intensity of RBD Employees with FhD and Master Degree\&I Intensity of app led national patents & $-0,11$ \\
\hline Resolution per engineer\& Case Qual ly & 0,35 \\
\hline Resolution per engineer\&Due Date Respongiveness & 0,91 \\
\hline Time Per Case[Po]|QNumber of Patents & $-0,31$ \\
\hline Percentage revenue from new products\& Intens"ty of Registered National Patents & 0,50 \\
\hline Percentage revenue from new product: \& Intensity of Registered Internatonal Patents & 0,32 \\
\hline Percentage revenue from new product: I Intensity of projects with Univergity-Industria Cooperation & 0,66 \\
\hline Percentage revenue from new product: \& Intensity of pubic founded projects & 0,85 \\
\hline Percentage revenue from new products \& Number of patents & 0,19 \\
\hline Number of training hours within the RQD activites\& Percentage revenue from new products & 0,50 \\
\hline Due Date Respongiveness[ BC]\& Rate of registered order change & 0,58 \\
\hline RQD expenditures per each employee \& Number of Patents & $-0,32$ \\
\hline RQD expenditures per each employee \& Percentage revenue from new products & 0,69 \\
\hline Rate of Regigtered Order change \& Percentage revenue from new products & 0,05 \\
\hline Rate of Regigtered Order change \& Turnover & 0,56 \\
\hline Resolution per enginger/Qpercentage revenue from new products & 0,64 \\
\hline RQD expenditures for ach employes \& Resolution per engineer & 0,25 \\
\hline Due Date resongiveness[BC] \& RRD expend tures per each emloyee & 0,14 \\
\hline Due Date repongiveness[BC] \& Percentage revenus from new product: & 0,33 \\
\hline Resolution per enginerk intensity of PhD and Master Degree & 0,38 \\
\hline Time Per Case(NPD) R Percentage Reveneue percentage revenue for new products. & 4,35 \\
\hline Time Per Cage $[\mathrm{PD}]$ \& Percentage Reveneu from new product: & $-0,55$ \\
\hline Due Date Reswrivenes[BCl\& Gase Quality & 0,54 \\
\hline Gese Qua Ity Intensity of RRD Employes with PHD and Master Degree & 0,13 \\
\hline
\end{tabular}


The results of this study were interpreted based on secondary in-depth interviews in order to investigate the reasons behind calculated scores The scores were examined from two directions during the interviews. The first one was the comments on growth part scores. As can be seen from the Figure 6, 2014 has the highest total growth score due to three main reasons according to the interviewees. The first reason is the low results of the KPIs in 2013 as in this year the company's location has changed and accordingly the financial growth has diminished due to the fact that many employees quit their jobs. Secondly, the financial growth was very high in 2014 because the company exported a very large R\&D project this year. Lastly, in 2014, there was a great increase in the amount of time spent for training R\&D staff, the greatest increase on the side of education and innovation due to the start of university-industrial cooperation. Further, the results of 2015 were evaluated as a significant success since the development and growth still proceed after the rapid growth in 2014, despite the decrease in the growth rate this year. In 2016, a large increase in the amount of orders received with a new agreement signed on the overseas market became the biggest factor in the growth of the customer side. However, in 2016 it was observed that there was a certain decline in terms of overall financial score mainly caused by the decrease in turnover. When the reasons behind this decrease are examined, it was seen that the political events and changes in the country, increasing exchange rates, global and geopolitical developments made 2016 as a challenging year for our sample company as well as all the companies in the sector. Additionally, a large portion of the company's shares are sold to another company in 2016 and as a result changes which happened in the company's structure become other reasons behind this financial decrease. However, both the increase in the number of patent applications, the continuing and even increasing industrialuniversity cooperation on the education and innovation side; the increase in the rate of the orders received and in the customer satisfaction on the customer side are the reasons for the company's development in general results despite the financial decrease. 

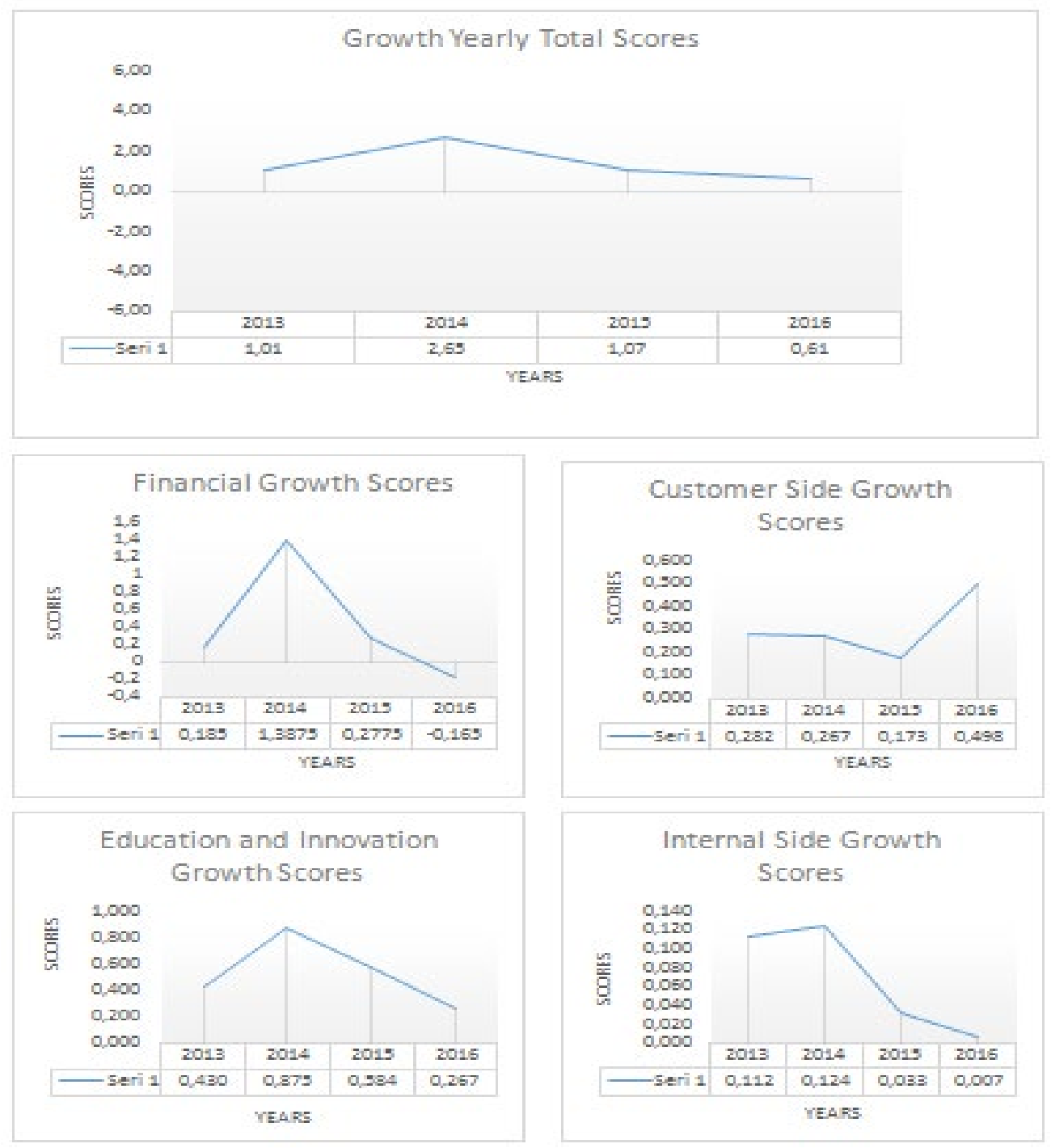

Figure 6: Growth Scores

The following results were achieved as a result of interviews on the goal achievement side scores(Figure 7) after the growth side was examined. In general, a great success has been gained in achieving targets throughout all the years. However, if we have to do a year-onyear review, the reason why goal achievement rate is the highest in 2104 is tha the targets set at the end of 2013 become at a lower level due to the fact that the company's location and thus the changes happened in the company structure. Moreover, 2015 can be considered as a very successful year in terms of achieving 2015 targets, because this year the targets were put ahead of the results of the previous successful year and realized mostly. Further, the main reason why the score was lowest on the customer side in 2015 was the unexpected decline in the registered order rate. However, this year has been a successful year in terms of other 
KPIs such as achieving the goals of the patent and maintaining the internal goals of the company. Despite the small decrease in goal achievement after a very successful year like 2014, 2015 was called a very successful year due the fact that the great success of the previous year has been continued. For the year 2016, financial targets could not be achieved due to the reasons mentioned on the growth side, yet the increase in the number of orders as a result of the breakthroughs made on the customer side has made this year the most successful year in terms of realizing the goals on the customer side.

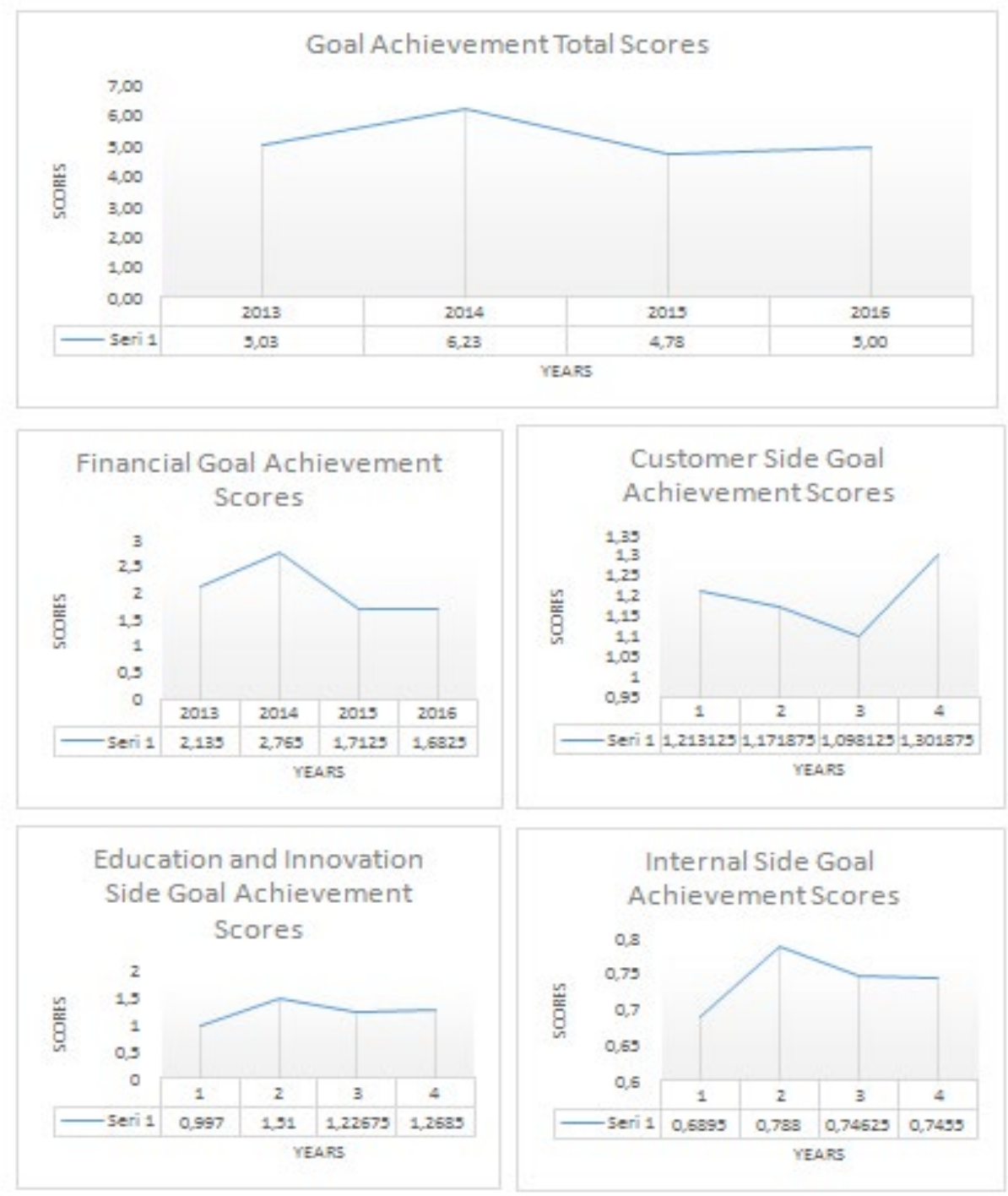

Figure 7: Goal Achievement Scores 


\subsection{Management Approach for the performance measurement system}

In the last part of the secondary in-depth interviews, managers were asked to think about new action steps they would like to take or current methods that they want to improve within the company's structure in order to implement the created performance measurement system within the company, According to the managers of the sample company, the first most important thing is to guarantee that each KPI can be measured accurately by the related department at the end of each year. To this end, each KPI is needed to be given to the related department with the targets set before by the managers. For instance, financial grouped KPIs should be given to the finance department; number of patent applications, number of registered patents, number of publication to the R\&D strategies department; software related KPIs to software design department. However, since measuring some KPIs especially software related KPI can be a very hard issue, an effective follow-up program system should be used in order to measure the KPIs on the software side accurately. The number of cases that a software engineer should resolve in a week should be determined by weekly review meetings and software cases should be assigned to the same experienced software in equal numbers and difficulty. In this context, a score should be given to each case according to the degree of its difficulty via using a project-tracking program. (e.g 10 is for the most difficult case 1 is for the easiest

At the end of each week, how many cases are solved and how many are still waiting to be solved should be saved. The KPI resolution per engineer can be easily calculated by this way. Further, Follow up programs have some features to record the time spent per case.To find out how much time each programmer has spent in a case, programmer/developer should press start button every time he starts a new case / stop button every time he stops working on the case/ finish button every time he finished the case. By this way, the possibility of accurately calculating the performance of KPIs such as time per case, time tracking utilization woould be higher. Further, It is clear that the innovation-side KPIs have more clear results as they are in numerical terms, but at this point some comments have been reached when it is asked what is neded to be done in order to improve the performance of the KPIs on the innovation side. Firstly, patent application number target must be set for the engineers and each patent written should be reviewed by another person than who wrote the patent to increase the likelihood of acceptance of the applications made. Also, attention to internship opportunities, thesis/ $\mathrm{PhD}$ studies should be given more to increase the cooperation with the universities . For example, internships on certain days during the school term may be accepted as a compulsory internship 
of the university, or students may be allowed to pursue doctoral studies / thesis studies at the company.

Lastlyi a table of results should be taken at the end of each month so that the outcomes of the measurements can be made easier and at the end of 12 months a numerical value to each KPI should be given according to the average of all months in that year.

\section{5) CONCLUSION}

The study shows that R\&D activities of the software sector mainly focus on solving the issues that come from customers, developing the current software, being sure about the software quality and creating a totally new software. However, development part of the R\&D is very crucial for the SWS as creating a totally new software is a challenging process.

The results of the study indicate that there are generally positive correlations between the software related KPIs' successes on the success of finance side or the success of innovation side. However, the results of some correlations did not show an expected behavior. For example, the intensity of R\&D Employees with Ph.D. and Master Degree and intensity of applied national patents has nearly negative correlation.

There are several limitations of this paper. Firstly, the study was conducted in a very limited time and the number of years from which the data collected was not high enough to make some deep statistical analysis. Secondly, some project based KPIs that they can only be evaluated within the project it belongs to could not be examined, as not all projects can be evaluated on a yearly basis. Some of them would last few months while some might last even for years.

There are a great deal numbers of contributions of this paper. Firstly, the study finds that the most appropriate performance measurement approach is Balanced Scorecard by making a detailed analysis among the most used PMFs. Secondly, this paper selects the most important KPIs which are suitable to software R\&D and suggests software related KPIs which are specific to $R \& D$ activities. As a result, this study presents a PMS particularly designed for the software R\&D activities .Further, the study enables the managers of software companies to evaluate the performance of $R \& D$ activities more effectively by giving a right decision-making perspective for the R\&D activities of their companies. Lastly, this paper offers a useful overview for the university lecturers who give innovation and R\&D related lectures and it can be a valuable sample for the future studies with similar subjects. 



\section{References}

An overview of the EFQM Excellence Model (2013). Retrieved from http://www.efqm.org/sites/default/files/overview_efqm 2013 v1.pdf

Balanced Scorecard Institute (n.d.). Balanced Scorecard Basics retrieved from: http://balancedscorecard.org/Resources/About-the-Balanced-Scorecard [accessed on :08.11.2016]

Bourne, M., Neely, A., Mills, J., \& Platts, K. (2003). Implementing performance measurement systems: a literature review. International Journal of Business Performance Management, 5(1), $1-24$.

Bremser, W. G., \& Barsky, N. P. (2004). Utilizing the balanced scorecard for R\&D performance measurement. R\&D Management, 34(3), 229-238.

Camp, R. C.(1989). Benchmarking: the search for industry best practices that lead to superior performance

Chesbrough, H. (2003). The logic of open innovation: managing intellectual property. California Management Review, 45(3), 33-58.

Chiesa, V., \& Frattini, F. (2009). Evaluation and performance measurement of research and development: Techniques and perspectives for multi-level analysis. Edward Elgar Publishing.

Daly, J.(2013, November 11). How Many Lines of Code Are in Your Favorite Software? (Online) http://www.statetechmagazine.com/article/2013/11/how-many-lines-code-are-yourfavorite-software-infographic (Accessed 10.01.2017)

Goldman, E. (2012, November 28). Fixing Software Patents. Retrieved from: https://www.forbes.com/sites/ericgoldman/2012/11/28/the-problems-with-softwarepatents/\#350cf99f4391 (Accessed 15.01.2017)

Hannon E. et al. ,2015) Brightening the Black Box of R\&D, (Online) http://www.mckinsey.com/business-functions/operations/our-insights/brightening-the-blackbox-of-r-and-d (Accessed 10.11.2016)

Jankowski, J., Tassey, G., Gallaher, M., Link, A. and Petrusa, J., 2005. Measuring servicesector research and development. Planning Report, pp.05-1.

Kaplan, R. S., \& Norton, D. P. (1996). The balanced scorecard: translating strategy into action. Harvard Business Press.

Kerssens-van Drongelen, I.C. and Bilderbeek, J. (1999) R\&D performance measurement: more than choosing a set of metrics. R\&D Management, 29, 1, 35-46.

Kulatunga, U., Amaratunga, D., \& Haigh, R.(2006) Performance measurement of research and development: A literature review.

Lazzarotti, V., Manzini, R., \& Mari, L. (2011). A model for R\&D performance measurement. International journal of production economics, 134(1), 212-223.

Lynch, R. and Cross, K. (1991), Measure Up! Yardsticks for Continuous Improvement, Basil Blackwell Inc, Cambridge, MA. 
Mossoff, A. (2014). A Brief History of Software Patents (and Why They're Valid).

National Research Council (US) Chemical Sciences Roundtable. (2003). Industrial Innovation with External R\&D Programs.

National Research Council.(2005)Measuring performance and benchmarking project management at the Department of Energy. National Academies Press, P. 21-24

Trueman D. Parish(1998)The Technology Value Pyramid: Assessing the Value of Research in the Chemical Sciences. National Academies Press

Neely, A. D., Adams, C., \& Kennerley, M. (2002). The performance prism: The scorecard for measuring and managing business success. London: Prentice Hall Financial Times.

Neely, A., \& Adams, C. (2000). Perspectives on performance: the performance prism. Focus Magazine for the Performance Management Professional, 4.

Rothwell, R. (1994). Towards the fifth-generation innovation process. International marketing review, 11(1), 7-31.

Somayajulu,C.

(2014).

Performance

Pyramid

(Online)

http://cvdsomayajulu.blogspot.com.tr/2014/03/performance-

pyramid 5679.html?view=classic (accessed 06.12.2016)

Striteska, M., \& Spickova, M. (2012). Review and comparison of performance measurement systems. Journal of Organizational Management Studies, 2012, 1.

Tian, D. 2013. "Comparison of r\&d efficiency of system, application and service software Companies.' International Journal of u- and e- Service, Science and Technology Vol. 6, No. 4, August, 2013: 169-180

Tregear, R. (2014,November 11). Why it is important to measure process performance, (Online) http://blog.leonardo.com.au/why-it-is-important-to-measure-process-performance , (accessed on: 16.12.2016)

Tsai, K. H., \& Wang, J. C. (2004). The R\&D performance in Taiwan's electronics industry: a longitudinal examination. $R \& D$ Management, 34(2), 179-189

UK ranks eighth globally for corporate R\&D spending, investing $£ 16.5$ bn last year (2016,October25)(Online)

http://www.strategyand.pwc.com/uk/home/press contacts/displays/2016-global-

innovation1000-study-uk (Accessed 02.02.2017)

Wongrassamee, S; Gardiner, P.D.; Simmons, J.E.L., 2003. Performance Measurement Tools: The Balanced Scorecard and the EFQM Excellence Model. Measuring Business Excellence; 7, 1: 14-29.

Yuregir, O. H., \& Nakıboglu, A. G. G. (2007). Performans Olcumu ve Olcum Sistemleri: Genel Bir Bakış. Çukurova Universitesi Sosyal Bilimler Enstitusu Dergisi, 16(2). 
